\title{
左室補助人工心臟装着患者の急性呼吸不全に対し非侵襲的陽 圧人工呼吸が著効した症例
}

\author{
田所 貴弘 神里 興太 照屋 孝二 \\ 㴊上 竜也 垣花学須加原一博
}

琉球大学医学部附属病院麻酔科 (T 903-0215 沖縄県中頭郡西原町字上原 207)

Key words: (1) left ventricular assist device (LVAD), (2) pulmonary edema, (3) noninvasive positive pressure ventilation (NPPV)

\section{はじめに}

非侵襲的陽圧人工呼吸 (noninvasive positive pressure ventilation, NPPV)による持続性気道内陽圧 (continuous positive airway pressure, CPAP) は心原性肺水腫への人 工呼吸療法の第一選択とされているが, 左室補助人工心 臓 (left ventricular assist device, LVAD) 植込み症例に 対する有用性を示した報告は少ない。一方 LVAD症例の 術後管理では, 早期リハビリ，感染症など多くの課題が 存在(1),2), NPPVの積極的な使用の有用性が示唆され る。

今回我々は, LVAD植込み術後における急性肺水腫に 対し，NPPVによるCPAPが奏効した症例を経験した。

\section{症 例}

症例：59歳, 男性。身長 $170 \mathrm{~cm}$, 体重 $55 \mathrm{~kg}$ 。

既往歴：2011年1月に陳旧性心筋梗塞, 高血圧を指摘 され, 他院で通院加療されていた。高脂血症, 糖尿病は 認めなかった。

生活歴：喫煙は 20 本/day 20 年間，飲酒は機会飲酒。

現病歴：2011年7月に労作時の胸痛を認め, 冠動脈造 影検查で左冠動脈前下行枝に 75 ～90\%の狭窄を認め, 経 皮的冠動脈形成術 (percutaneous coronary intervention, PCI）を施行された。しかし，PCIから10日後に心不全症 状, ステント内狭窄を認めたため, 経皮的冠動脈バルー ン拡張術を施行した。その 2 日後にも再び心不全症状が 出現し, 大動脈バルーンパンピング (intra-aortic balloon pump, IABP）を開始した。その後も左心機能の改善はそ しく, 初回のPCIから55日後に経皮的心肺補助装置 (percutaneous cardiopulmonary support, PCPS) での管 理を開始した。重症心不全で内科的治療は困難と判断し 当院に転院となり, LVAD植込み術〔機種：TOYOBO
LVAS (東洋紡)]を施行された。術前経胸壁心エコーで は前壁から前壁中隔，後壁にかけて無収縮であり左室駆 出率は $13 \%$ だった。

術後8日目にカテコラミン投与は終了し, 術後14日目 から心臓リハビリを行っていた。

抗血小板療法としてバイアスピリン $100 \mathrm{mg}$, 抗凝固療 法としてワルファリン $4 \mathrm{mg}$ 大服しており, prothrombin time-international normalized ratio (PT-INR) 值は 3.0〜 4.5にコントロールしていた。

\section{経 過}

LVAD植込み術後 69 日目に, 軽度の頭痛, 見当識障害 を認めた。頭部 CT検査上, 左後頭側頭葉に $3 \times 5 \mathrm{~cm}$ 大 の鏡面像を伴う楕円形の血腫と考えられる高吸収域を認 めた。PT-INR值は3.96だった。

新鮮凍結血漿 $(80 \mathrm{~m} l / \mathrm{hr}$, 計 $720 \mathrm{~m} l)$, 輸液 $(60 \mathrm{~m} l$ ) $\mathrm{hr})$, グリセオール $(400 \mathrm{ml})$, ビタミン $\mathrm{K}(20 \mathrm{mg})$ 投与を 行った。LVADの設定は[\% SYS] 35\%, [RATE] $65 / \mathrm{min}$ であり, 変更は加えなかった。

輸血開始から 10 時間後, 呼吸様式に変化はなかったが, 徐々に $\mathrm{SpO}_{2}$ が低下し, 動脈血液ガス分析で $\mathrm{PaO}_{2} 67.1$ $\mathrm{mmHg}\left(\mathrm{SpO}_{2} 96 \%\right)$ と酸素化の悪化を認めたため, 酸素 投与を開始した。

14 時間後から急激に呼吸困難が増悪し, 酸素 5 lマスク 投与下で $\mathrm{SpO}_{2} 79 \%$ と酸素化は悪化傾向だった。15時間 後 (増悪 1 時間後) には頻呼吸, 冷感, 心拍数上昇 (150 / min) を認め, 両肺でラ音 (水泡音) が聴取された。心電 図上は心拍数が $80 / \mathrm{min}$ から徐々に $150 / \mathrm{min}$ まで上昇し たが, P波の増高など伝導系に変化は認めなかった。

利尿薬, 酸素投与では症状改善せず, NPPV (PEEP 10 $\left.\mathrm{cm} \mathrm{H}_{2} \mathrm{O}\right)$ が開始された。利尿薬は継続した。NPPV 開始 30 分後には症状は劇的に改善し, 3 時間後に循環動態も

Effectiveness of noninvasive positive pressure ventilation for acute respiratory failure in a patient with left ventricular assist device

Takahiro Tadokoro, Kota Kamizato, Koji Teruya, Tatsuya Fuchigami, Manabu Kakinohana, Kazuhiro Sugahara

Department of Anesthesiology, Faculty of Medicine, University of the Ryukyus (207 Uehara, Nishihara-cho, Nakagami-gun, Okinawa 903-0215, Japan) 


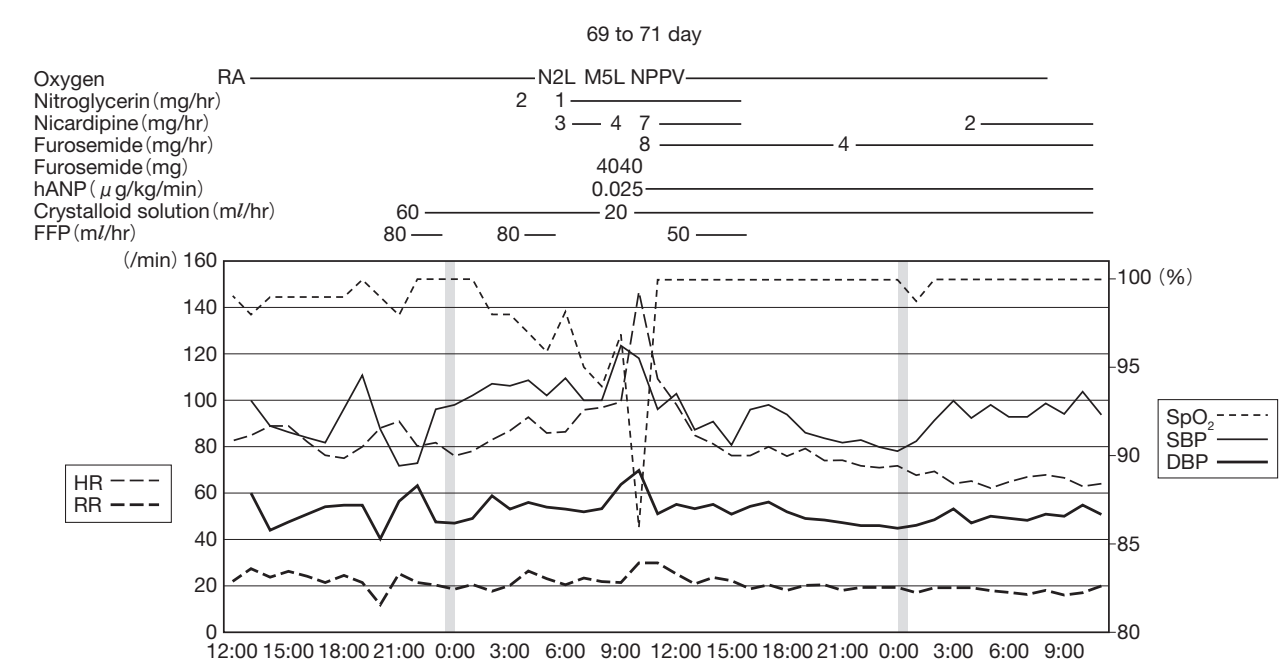

Fig. 1 Clinical course and treatment in the ICU from postoperative day 69 to 71

$\mathrm{SpO}_{2}$ was increased, and HR is decreased after the application of NPPV.

DBP, diastolic blood pressure; FFP, fresh frozen plasma; hANP, human atrial natriuretic peptide; $\mathrm{HR}$, heart rate; M5L, mask $5 l$; N2L, nasal $2 l$; NPPV, noninvasive positive pressure ventilation; RA, room air; RR, respiratory rate; SBP, systolic blood pressure.

平常時に戻った。

NPPVは 22 時間で終了し, その後呼吸状態の増悪なく 経過した。尿量は 22 時間で約 $4,000 \mathrm{~m} l$ だった。

\section{考 察}

臨床症状 (呼吸困難, 低酸素血症), 胸部 X 線上の肺血 管陰影の増強から, 急性肺水腫と考えられる。輸血関連 肺障害も鑑別に挙がるが, 症状発現が輸血開始後 10 時間 後であることから否定的である。

急性肺水腫の原因として脳出血による神経原性肺水腫 も考えられたが, 中枢神経系の症状は軽度であり, 交感 神経系の著明な立進が主因の神経原性肺水腫は否定的で ある。容量負荷開始後に酸素化が悪化しており, 経過か ら容量負荷による急性肺水腫と考えられる。

これまでの報告で, NPPVの効果として胸腔内の陽圧 化による前負荷, 後負荷の軽減, また肺胞虚脱の抑制効 果が挙げられ3), 急性心不全治療, 特に心原性肺水腫に対 し有効であり, 早急に行うことが強く推奨されている4)。

本症例では, 呼吸困難が急激に増悪し, 頻呼吸, 心拍数 の増加をきたしたため, 速やかにNPPVを開始した。 NPPV 開始直後から著明に呼吸困難は改善し, 呼吸数の 減少, 酸素化の改善が得られたため, NPPVが有効だった と判断できる5)。

本症例のようにLVADが導入されている場合, 容量負 荷に応じた心拍出量の増加は見込めない。そのため, NPPVにより前負荷を減少させ, 利尿薬によって循環血 液量を適正化し, 右心不全に至ることなく急性肺水腫を 改善できる。

容量負荷に応じLVADの固定拍出回数を増加させれ ば, 肺水腫を回避できた可能性はあると考えられるが, 今回は行っておらず，その効果は不明である。

本症例で挿管管理に比べてNPPVが有利な点として は, 呼吸状態の改善後に速やかに中止し人工呼吸管理期 間を短縮することで, 心臓リハビリの早期再開ができる ことが挙げられる。
NPPVにより左室前負荷は減少したが, 駆出状況や血 圧変動をみる限り, LVADの充填量は十分であり拍出量 も保たれたため, 体循環が安定していた。

\section{結 論}

LVAD治療中患者において, 容量負荷のような急激な 前負荷増大がみられる病態でのNPPVによる初期治療が 有効であった症例を経験した。

本稿の全ての著者には規定されたCOIはない。

\section{文 献}

1) $\mathrm{Oz} \mathrm{MC,} \mathrm{Argenziano} \mathrm{M,} \mathrm{Catanese} \mathrm{KA,} \mathrm{et} \mathrm{al.} \mathrm{Bridge}$ experience with long-term implantable left ventricular assist devices. Are they an alternative to transplantation? Circulation 1997;95:1844-52.

2) Drakos SG, Janicki L, Horne BD, et al. Risk factors predictive of right ventricular failure after left ventricular assist device implantation. Am J Cardiol 2010;105:1030-5.

3) Masip J, Roque M, Sánchez B, et al. Noninvasive ventilation in acute cardiogenic pulmonary edema: systematic review and meta-analysis. JAMA 2005;294:3124-30.

4) Dickstein K, Cohen-Solal A, Filippatos G, et al; ESC Committee for Practice Guidelines (CPG). ESC Guidelines for the diagnosis and treatment of acute and chronic heart failure 2008: the Task Force for the Diagnosis and Treatment of Acute and Chronic Heart Failure 2008 of the European Society of Cardiology. Developed in collaboration with the Heart Failure Association of the ESC (HFA) and endorsed by the European Society of Intensive Care Medicine (ESICM). Eur Heart J 2008;29:2388-442.

5) 藤野裕士, 内山昭則, 西村匡司, 他. 大手術後の抜管後呼 吸不全に対する非侵襲的人工呼吸. 日集中医誌 2002;9:207-11. 